\title{
Аналіз досвіду організації об’єднаної (міжвідомчої) підготовки у провідних країнах світу
}

\author{
Олег Гавалюх 1 А; Володимир Харабара 2 в \\ А Національний університет “Одеська морська академія”, ул. Градоначальницька, 20, м. Одеса, 65029, Україна

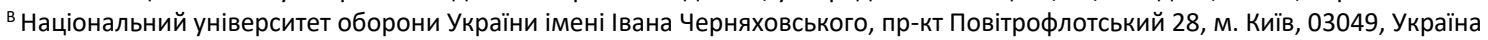

Received: December 20, 2020 | Revised: January 20, 2021 | Accepted: February 28, 2021

DOI: $10.33445 /$ sds.2021.11.1.1

\begin{abstract}
Анотація
Застосування військових частин та підрозділів Збройних Сил України спільно з військовими формуваннями інших відомств в антитерористичній операції та в операції об'єднаних сил на сході держави вказало на ряд недоліків підготовки складових сектору безпеки й оборони. Підготовки повинна забезпечувати набуття спроможностей як самостійно виконувати завдання за призначенням так і спільно в складі об'єднаних угруповань та тактичних груп.

Необхідність впровадження нових підходів до підготовки сил безпеки й оборони, потребують удосконалення організації об'єднаної підготовки. На основі аналізу організації об'єднаної (міжвідомчої) підготовки, визначити принципові напрями для підвищення ефективності підготовки підрозділів сектору безпеки й оборони держави.

Стаття висвітлює результати аналізу організації об'єднаної (міжвідомчої) підготовки в провідних країнах світу і має на меті оприлюднити необхідні напрямків розвитку підготовки складових сектору безпеки й оборони. Дозволить виділити головні напрямки, що в подальшому надасть можливість формувати необхідні рекомендацій з метою покращення функціонування системи підготовки складових сил оборони.
\end{abstract}

Ключові слова: сили оборони, об'єднана підготовка, аналіз досвіду, організація, провідні країни світу.

\section{Постановка проблеми}

Аналіз тенденцій зміни характеру воєнних конфліктів останніх десятиліть дає можливість стверджувати, що сьогодні зміст війни полягає вже не в розгромі збройних сил противника, а в тому, щоб нанести максимальні втрати політичній волі, населенню, економіці та інфраструктурі держави-жертви агресії, тим самим підпорядкувати цю державу своїй волі.

Вимоги практичної діяльності сил оборони держави визначило низку завдань перед теорією підготовки сил оборони до спільного виконання завдань щодо захисту суверенітету, територіальної цілісності.

Зміни, які відбуваються у зв'язку 3 розвитком системи підготовки складових сил оборони, впровадження нових доктринальних документів 3 питань застосування сил оборони держави зумовлюють підвищення вимог до їх підготовки. [1, 2, 3].

\section{Аналіз останніх досліджень та публікацій}

Аналіз останніх досліджень свідчить, що, віддаючи належне науковим напрацюванням із цієї проблематики, слід зауважити, що дослідження теоретичних аспектів взаємодії між військовими формуваннями сил оборони під час виконання завдань із забезпечення

\footnotetext{
${ }^{1}$ Corresponding author: к.в.н., заступник начальника інституту, e-mail: hr@naval.onma.edu.ua, ORCID: 0000-0001-8307-4002

2 к.в.н., старший викладач кафедри, e-mail: ivanovuth@ukr.net, ORCID: 0000-0001-7912-6578
} 
національної безпеки держави ще не мають скоординованого і системного характеру, а розробки із цієї проблематики слабо узгоджуються між науковими установами та окремими дослідниками [4, 5].

Відсутність загальноприйнятих теоретичних розробок з організації об'єднаної підготовки та відповідних рекомендацій, які $б$ відповідали реаліям сьогодення, значно знижує ефектив- ність підготовки військових формувань. Ураховуючи те, що організація об'єднаної підготовки $є$ складною системою, основи якої закладаються в рішенні на організацію підготовки сил оборони, а весь комплекс узгоджених дій відбивається у відповідних документах, підтримується і за необхідності уточнюється залежно від умов $[6,7]$.

\section{Постановка завдання}

Актуальність проблеми, ії недостатня теоретична розробленість і практичне значення обумовили необхідність визначити: головні напрямки розвитку організації об'єднаної підготовки сил оборони держави.

\section{Виклад основного матеріалу}

Враховуючи відсутність інформації щодо організації спільної підготовки у збройних силах провідних країн світу, за основу взято аналіз постконфліктних операцій, що здійснювались збройними силами США в Афганістані й Іраку [8].

Операції збройних сил США в Афганістані та Іраку виявили цілий ряд проблем, серед яких особливе місце займає неналежним чином налагоджена взаємодія між військовим керівництвом розгорнутих у цих країнах формувань, що належать міністерству оборони, і представниками інших, головним чином урядових організацій, таких, наприклад, як Державний департамент.

Великим прорахунком американського військово-політичного керівництва із самого початку обох бойових операцій на Великому Близькому Сході була відсутність детально перелічених викликів і сукупних заходів щодо їхньої нейтралізації. Виявилося також, що силами тільки міністерства оборони всі ці проблеми вирішити не представляється можливим. У цьому зв'язку деякі американські фахівці в області військовополітичних проблем виражають подив, чому
Метою зазначеної статті $€$ оприлюднення результатів аналізу об'єднаної (міжвідомчої) підготовки, визначення напрямків розвитку організації підготовки сил безпеки й оборони держави.

військове відомство було фактично захоплене зненацька валом проблем, що звалилися, по суті, на окупаційні війська США В зазначених державах, якщо те ж міністерство оборони, будучи спадкоємцем національних силових структур IX і середини XX століття не врахувало раніше напрацьований досвід у Мексиканській і Громадянській війнах, післявоєнному врегулюванні в Німеччині, Японії (Друга світова війна) і Південній Кореї.

Практично відразу після капітуляції військ Саддама Хусейна у 2003 році з ініціативи адміністрації Джорджа Буша (молодшого) почалося відновлення або вдосконалювання концептуально-нормативної бази міжвідомчого співробітництва.

Розробники цієї бази, відштовхуючись від фундаментального "Закону про національну безпеку" від 1947 року [9], насамперед постаралися розібратися 3 головним поняттям - “міжвідомчість". у їхньому трактуванні - це спільна, у координації, робота управлінь, департаментів, агентств i організацій державного (урядового) підпорядкування, спрямована на забезпе- 
чення інтересів національної безпеки. При цьому створювана для реалізації такої політики група (команда) може включати представників і неурядових організацій, якщо потрібне нарощування активності в якомунебудь певному напрямку діяльності. Загальний нагляд за міжвідомчою роботою здійснює секретар Ради національної безпеки.

Що стосується конкретних аспектів міжвідомчої діяльності, то продовж півтора року на надрах президентської адміністрації, Міністерства оборони й Державний департамент розробляли і до кінця 2005 р. було затверджено ряд документів, які, як передбачалося, повинні були максимально закрити прогалини В нормативному забезпеченні взаємодії державних установ, насамперед там, де в цьому виникала така необхідність.

Насамперед, було потрібно налагодження взаємодії саме в постконфліктних операціях, які, за узгодженням, розділили, на три види: стабілізаційні (по забезпеченню безпеки), перехідні й відбудовні. Спочатку, 28 листопада 2005 року, була опублікована Директива міністра оборони 3000.05 "Військове забезпечення постконфліктних операцій". Через тиждень Президентська директива NSPD-44 “Керування міжвідомчими зусиллями в області відновлення й стабілізації".

Ці директиви в сукупності з'явилися тією базою, на якій і повинна була будуватися вся робота військового й інших відомств по перетворенню вказівок державного керівництва в життя.

Слідом за цими фундаментальними документами Об'єднане командування єдиних сил ЗС США, покликане, крім іншого, розробляти “об”єднані" (міжвідомчі) статутні документи й настанови, через підлеглий йому Центр вивчення досвіду й аналізу бойових дій у взаємодії з Управлінням координатора по реконструкції й стабілізації, утвореним у Державному департаменті, підготувало ще один концептуальний документ - “Рамки проекту планування керівництвом США реконструкції, стабілізації й конфліктній трансформації", покладений в основу міжвідомчого планування процесу постконфліктних операцій.

У всіх зазначених документах констатується той факт, що границі між функціями військового й цивільного відомств при здійсненні постконфліктних операцій розмиті й що вони не можуть вирішуватись тільки військовими засобами. Було зроблено висновок, що для їхньої ефективної реалізації потрібні стандартні, погоджені програми підготовки керівних кадрів, які взяли на себе всю відповідальність за успішне здійснення таких операцій. Частково відповіді на питання, кому це можна доручити і як це зробити, знайшли відбиття в Указі президента від 17 травня 2007 року про Розвиток професійної підготовки в області національної безпеки. Американські аналітики відзначають, що даним питанням, у принципі, i раніше приділялася певна кількість годин занять у видових й об'єднаних командно-штабних коледжах ЗС США, де проходять навчання в тому числі й цивільні чиновники із цілого ряду державних установ виконавчої влади. Більше того, аналогічні програми підготовки як цивільних, так і військових керівників в області “міжвідомчої взаємодії” є в Школах Кеннеді, Максвелла й деяких інших престижних військових організаціях. Спеціальний інструктаж керівників постконфліктних операцій 3 недавніх пір став проводитися в Об'єднаному центрі бойової підготовки у Форт-Полк (шт. Луїзіана) й в Інституті миротворчих i 
стабілізаційних операцій у Казармах Карлайсл (шт. Пенсільванія). Проте стурбовані відсутністю висококваліфікованих кадрів і недостатністю рівня підготовки керівників подібного роду операцій Міністерство оборони й Державний департамент в 2006 році спільно організували спеціальний навчальний заклад під умовною назвою "Центр комплексних операцій”, навчальна програма якого повністю присвячена нюансам планування, підготовки, здійснення постконфліктних операцій i керівництва ними у всьому їхньому обсязі.

Крім цього, включено в програми навчання особового складу тему міжвідомчого співробітництва у військових вузах і на курсах позавійськової підготовки офіцерів запасу при цивільних вузах (ROTS).

Підбору й підготовці керівників міжвідомчих команд і операцій у США приділяється особлива увага. Специфічні умови здійснення таких операцій, як правило, викликані необхідністю командного стилю керівництва ними. Природна "мілітаризація міжвідомчих відносин" в умовах постконфліктної обстановки була навіть відзначена в Президентській директиві PDD56 від 1997 року. На практиці це означає, що структури й функції міжвідомчих команд (груп) повинні бути на зразок військових, із чіткими лініями керівництва й домінуванням принципу єдиноначальності. Коли одна особа, призначена керівником, має право визначати представника інших організацій, що входять у групу, яка відповідає за виконання того або іншого приватного завдання в рамках загальної місії.

При цьому, що важливо підкреслити, відповідно до згаданої вище президентської директиви NSPD-44, провідною інстанцією в справі організації й здійсненні постконфліктних операцій призначався
Державний департамент i, зокрема, що згадувалося вище, Управління координатора по реконструкції й стабілізації. Інакше кажучи, саме на дане управління покладено “обов'язок координації й установлення робочих відносин з відповідними американськими організаціями в справі підготовки плану й здійснення стабілізаційних і відбудовних дій". Природно, це не означає, що переважне право керівництва міжвідомчою командою належить Державного департаменту. 3 огляду на специфіку постконфліктних операцій, перевага, швидше за все, буде віддаватися представникам військового відомства.

У цьому зв'язку американські дослідники п. Смит і Д. Джерстайн приводять такий характерний приклад з історії міжвідомчої постконфліктної операції по наданню гуманітарної допомоги населенню Гаїті в 1994 р. Незважаючи на те що керівником операції було призначено цивільну особу представника однієї із цивільних урядових організацій США, справа з упорядкуванням поставок була організована настільки погано, що якби обов'язки по координації міжвідомчих зусиль спонтанно не звалив на себе командувач, у ті роки, Атлантичним об'єднаним командуванням ЗС США адмірал Дэвид Міллер, крах всієї операції був би неминучий.

Перевага, що віддається “людям у погонах" як керівників міжвідомчих команд, автоматично привертає увагу фахівців до підвищених вимог, які повинні пред'являтися до військових керівників у настільки складних місіях. Так, один $з$ дослідників проблеми лідерства, в цілому, Вальтер Алмер вказує: “Незважаючи на те, що в загальному плані вимоги як до цивільних, так і до військових лідерів ідентичні, у приватних питаннях існують принципові особливості...". 
По-перше, у постконфліктних операціях, що б там не говорили, військові піддаються більшій небезпеці, ніж цивільні, оскільки насамперед вони, як показує статистика, $\epsilon$ об'єктами нападів.

По-друге, у військових традиційно відповідальність за доручену справу вище, i запитують із них значно жорсткіше. На думку Алмера, при виборі військового як керівника по суті змішаної цивільно-військової команди завжди треба враховувати факт споконвічно властивим військовим керівникам таких якостей, як намір домінувати, схильність до володіння точними даними (ніж перевага до імпровізації або інтуїції), авторитаризм і вимога до беззаперечної лояльності з боку підлеглих.

Американськими аналітиками помічено, що 3 вибором керівників міжвідомчих команд із числа військових, як правило, проблем не виникає, тому що вся система виховання офіцера саме й спрямована на вирощування лідера. Більше того, цим аспектам у військовому відомстві США завжди приділялося й приділяється пильна увага, у тому числі в області розробки нормативних документів, якими керуються військові у своєму службовому росту.

Зокрема, у жовтні 2006 р. під керівництвом тодішнього начальника штабу сухопутних військ США генерала Питера Шумейкера була розроблена остання за часом версія Польового статуту FM 6-22 “Військове керівництво у СВ: компетентність, надійність, адаптивність", що став основою для розробки подібних статутів в інших видах американських збройних сил. У цьому фундаментальному документі досить докладно викладені вимоги до військових керівників на всіх рівнях, у тому числі стратегічному, що передбачає керування й “невоєнними" організаціями.
Причому, як зразки керівників такого рівня наведені не тільки прізвища військових (генерала Джорджа Маршалла), але й цивільних, таких осіб як Генрі Форд, тощо.

В колах політичного істеблішменту Вашингтона в цілому згодні з військовими відносно підвищених вимог до керівників, у тому числі цивільних, при здійсненні постконфліктних операцій.

Урядові організації, такі як Державний департамент, Агентство США по міжнародному розвитку, Управління по справах федеральних службовців (УСФС), ЦРУ й інші, мають спеціальні процедури пошуку, відбору й підготовки осіб, що володіють навичками лідерства.

Серед перерахованих організацій провідною в даній області $€$ УСФС, на яке в тому числі покладений обов'язок по виявленню серед цивільних тих, кому може бути доручене керівництво змішаними колективами.

Існує припущення про розширення діапазону вимог при підборі чиновників на керівні міжвідомчі посади, включаючи обов'язкову наявність навичок комунікабельності, а також здійснення загальної “сертифікації лідерства" у даній області в середовищі державних чиновників кандидатів на керівну роботу в змішаних колективах.

Керівник міжвідомчої команди, будь він із числа військових або цивільних, повинен усвідомлювати той факт, що для успішного виконання місії потрібно не просто координація дій складових міжвідомчої команди елементів від різних організацій, а “єдність зусиль у політичній, військовій, економічній і психологічній областях... де невоєнні засоби найчастіше грають куди більшу роль, чим інші".

Головні труднощі в здійсненні даної місії 
полягають у тім, що внутрішньовідомча культура, традиції, мотивація у різних елементів єдиної, здавалося б, команди значно розрізняються. Наприклад, підкреслюють згадувані аналітики П. Смит і Д. Джерстайн, звичайно Державний департамент легко схиляється до рекомендацій із силового втручання, а Міністерство юстиції більше стурбовано законністю кроків, що вживаються, що відразу породжує суперечки.

Міністерство оборони завжди виступає за складання докладного плану дій, тоді як інші відомства, по досвіду, більше схильні до імпровізації. 3 іншого боку, у військових, як правило, відсутні політичне чуття й глибокі знання місцевої специфіки, що мимоволі підштовхує їх до бажання “проломити" рішення. У тих же питаннях, які стосуються необхідності прямого залучення в конфлікт збройних сил, представники військових практично завжди працюють як “центр стримування", не квапляться, запитують можливо більшу кількість даних, деталей щодо передбачуваної місії, тимчасових графіків, очікуваних результатів тощо.

Відзначаються й випадки різкої розбіжності інтересів у відомств, що делегували в команду своїх представників. Найбільше часто це має місце у взаєминах Міністерства оборони й Державного департаменту.

Часом бувають випадки, коли у міжвідомчій команді переважає думка того відомства, керівник якого ближче до Президента або Конгресу, чим його колегиопоненти.

Якщо ж відомства конструктивно, 3 бажанням, підходять до рішення проблеми, заздалегідь обумовлюють свої ролі в заході, збоїв, як правило, не буває. У якості позитивного звичайно приводиться приклад роботи напередодні підписання Дейтонських угод по Балканам в 1995 р., коли представники Міністерства оборони, Об'єднаного штабу і Державного департаменту докладно опрацювали питання, потім домоглися схвалення його у конгресі й успішно втілити задумане в життя.

Незважаючи на достатню кількість регламентуючих документів, що визначають міжвідомчу взаємодію в сучасних умовах, професіонали-практики змушені констатувати наявність цілого ряду проблем, які необхідно розв'язати.

Серйозно ускладнює взаємодію представників різних відомств відсутність загального докладного термінологічного апарату. Американські фахівці відзначають, що багато термінів, наприклад, по-різному трактуються в Міністерстві оборони й Державному департаменті. До таких термінів, зокрема, віднесені наступні актуально важливі: “операції проти повстанців", "відтворення держави", “безпека", “просування демократії" тощо. А терміну "тероризм" взагалі існує порядку десяти трактувань, у тому числі й на офіційному рівні.

Інша проблема, 3 якою може зіштовхуватися міжвідомча команда, коли їй уже поставлені завдання й позначені пріоритети, - це відсутність відповідної підготовки й досвіду в багатьох представників відомств, виділених для виконання місії. Справа в тому, що американська практика останніх десятиліть свідчить про те, що подібні команди створюються звичайно на тимчасовій основі, у яких від цивільних відомств делегуються аж ніяк не самі здатні для даної педантичної справи представники. Військові ж, неодноразово зіштовхуючись із постконфліктними ситуаціями, з деяких пір стали більш відповідально підходити до даної проблеми й, хоча $б$ у своєму колі, заздалегідь 
стали визначати тих посадових осіб зі служб, яким, швидше за все, прийдеться займатися розв'язанням наступної конфліктної обстановки Та й цивільні представники змінюються набагато частіше, особливо якщо місія виконується в районах з ускладненими кліматичними й, тим більше, військовополітичними умовами, що не сприяє зімкненню міжвідомчого колективу.

Із цього робиться висновок про необхідність домагатися створення стабільних, заздалегідь підготовлених спільних колективів співробітників від різних відомств. Далеко за прикладом, указують американські аналітики, ходити не треба. Так, Німеччина й Великобританія, вивчивши негативний досвід США в Афганістані по формуванню постконфліктних так званих груп відновлення провінцій, заздалегідь, у передбаченні розробленого (схваленого) рішення НАТО про постконфліктне урегулювання, сформували, натренували й направили в регіон цілком дієздатні міжвідомчі команди фахівців різного профілю. При цьому підбору професіоналів зі знанням місцевих мов і перекладачів приділялася не остання увага.

у цілому, складну ситуацію навколо міжвідомчих операцій американські дослідники схильні порівнювати 3 положенням у збройних силах США в другій половині 80-х років минулого століття, коли було поставлене завдання раз і назавжди звільнитися від "видового егоїзму", згуртувати ЗС у єдине “об'єднане” ціле. Для цього передбачався величезний комплекс заходів, включаючи обов'язкове проходження перспективних військовослужбовців, що претендують на генеральські звання, через так звані “об'єднані" (міжвидові) посади в штабах і командуваннях.

Щось подібне пропонується зробити й в області міжвідомчої взаємодії, уже коли зрозуміють на найвищому рівні, що постконфліктна фаза врегулювання із залученням до нього представників різних відомств стає практично неминучою в будьякому збройному конфлікті.

Більше того, було запропоновано аспекти міжвідомчої взаємодії, які стали обов'язковою функцією збройних сил, включити в запланований до публікації в 2009 р. фундаментальний документ військового відомства за назвою "Всебічний огляд стану й перспектив розвитку ЗС США", тим самим виводячи оборонні потреби країни за рамки військового відомства з усіма далеко, що йдуть наслідками, цього кроку.

\section{Висновки}

Виконання спільних завдань у постконфліктних операціях спонукало збройні сили США до впровадження міжвідомчої підготовки. Було проведено комплекс заходів по відпрацюванню керівних (плануючих) документів та організована підготовка кваліфікованих спеціалістів у відповідних навчальних закладах для виконання спільних завдань у пост конфліктних операціях. Зазначене, ще раз підтверджує про необхідність проведення вказаних заходів складовими сил безпеки й оборонм України для захисту національних інтересів та підвищення рівня обороноздатності країни.

\section{Список використаних джерел}

1. Доктрина застосування сил оборони держави: за станом на 31 берез. 2020 р./
Генеральний штаб Збройних Сил України. Офіц. вид. - К.: Ген. штаб. вид-во, 2020. - 
35 с. (Нормативний документ Генерального штаб Збройних Сил України. Доктрина).

2. Доктрина об'єднаної підготовки сил оборони держави: за станом на 21 січня. 2020 р./ Генеральний штаб Збройних Сил України. Офіц. вид. - К.: Ген. штаб. вид-во, 2020. 26 с. (Нормативний документ Генерального штаб Збройних Сил України. Доктрина).

3. Єдиний перелік (каталог) спроможностей Міністерства оборони України, Збройних сил України та інших складових сил оборони: за станом на 09 грудня. 2020 р. / Міністерство оборони України. - Офіц. вид. - К.: Мін. оборони. вид-во, 2020. - 626 с. (Нормативний документ Міністерства оборони України. Каталог).

4. Сиротенко А. М. Сучасні погляди на форми та способи застосування угруповань військ (сил) Збройних сил України, інших військових формувань та правоохоронних органів держави під час спільних дій: к.т.н / А.М.Сиротенко // Збірник тез доповідей П’ятої Всеукраїнської науково-практичної конференції “Спільні дії військових формувань і правоохоронних органів держави: проблеми та перспективи". 2018. 08-10 c.

5. Заблоцький В. Забезпечити перемогу У великій війні-К., 1923 [Електронний ресурс]
/ Матеріали друкованого видання “Ідеологія здорового глузду". URL: https://tyzhden.ua/ World/228985.

6. Хома В. В. Вимоги до спільної підготовки і застосування збройних сил та державної прикордонної служби України: Збірник тез доповідей Міжнародної науково-практичної конференції "Інтегроване управління кордоном. Теорія і практика". - 2013. - С. 132-133.

7. Яким'як С. В. Проблемні питання застосування сил (військ) ВійськовоМорських Сил Збройних Сил України у складі міжвидових і міжвідомчих угруповань та шляхи їх вирішення: к.в.н / С. В. Яким'як // Збірник тез доповідей П'ятої Всеукраїнської науково-практичної конференції “Спільні дії військових формувань і правоохоронних органів держави: проблеми та перспективи". - 2018. - С. 16-17.

8. Печуров С. Л. Военные профессионалы в англо-саксонской модели управления вооруженными силами: история и современность. М.: ЛЕНАНД, 2010. - 176 с.

9. Закону про національну безпеку: за станом на 26 лип. 1947 р./ Когрес США. - Офіц. вид. - В: Когрес США. вид-во, 1947. - 17 с. (Нормативний документ США. Закон).

\title{
Анализ опыта организации объединенной (межведомственной) подготовки в ведущих странах мира
}

\author{
Олег Гавалюх ${ }^{1}$ А; Владимир Харабара 2 в \\ ${ }^{1}$ Corresponding author: к.в.н., заместитель начальника института, e-mail: hr@naval.onma.edu.ua, ORCID: 0000-0001-8307-4002 \\ 2 к.в.н., старший преподаватель кафедры, e-mail: ivanovuth@ukr.net, ORCID: 0000-0001-7912-6578 \\ А Национальний университету “Одесская морская академия”, ул. Градоначальницкая, 20, м. Одеса, 65029, Украина \\ в Национальный университет обороны Украины, пр-кт Воздухофлотский, 28, г. Киев, 03049, Украина
}

\begin{abstract}
Аннотация
Применение воинских частей и подразделений Вооруженных Сил Украины совместно с военными формированиями других ведомств в антитеррористической операции и в операции объединенных сил на востоке государства указал на ряд недостатков подготовки составляющих сектора безопасности и обороны. Подготовка должна обеспечивать приобретение способностей как самостоятельно выполнять задачи по назначению, так и
\end{abstract}


совместно в составе объединенных группировок и тактических групп.

Необходимость внедрения новых подходов к подготовке сил безопасности и обороны, требуют совершенствования организации объединенной (межведомственной) подготовки.

На основе анализа организации объединенной (межведомственной) подготовки, определить принципиальные направления повышения эффективности подготовки подразделений сектора безопасности и обороны государства.

Статья освещает результаты анализа организации объединенной (межведомственной) подготовки в ведущих странах мира и имеет целью обнародовать необходимые направлений развития подготовки сектора безопасности и обороны. Позволит выделить главные направления, а дальнейшем позволит формировать необходимые рекомендации с целью улучшения функционирования системы объединенной (межведомственной) подготовки.

Ключевые слова: силы обороны, объединенная подготовка, анализ опыта, организация, ведущие страны мира.

\title{
Analysis of the experience of the united (interdepartmental) training in the leading countries of the world
}

\author{
Oleh Havaliukh ${ }^{1}$ A; Volodymyr Kharabara ${ }^{2 B}$ \\ ${ }^{1}$ Corresponding author: PhD, Deputy officer - in - command on academics, e-mail: hr@naval.onma.edu.ua, ORCID: 0000-0001-8307-4002 \\ ${ }^{2}$ Candidate military science, Senior instructor of department, ORCID: 0000-0001-7912-6578 \\ A National University “Odessa maritime academy", 20, Gradonachalnick, st., Odessa, 65029, Ukraine \\ B National Defense University of Ukraine named after Ivan Chernyakhovskyi, 28, Vozduhoflotsky, ave, Kyiv, 03049, Ukraine
}

\begin{abstract}
The use of military units and subdivisions of the Armed Forces of Ukraine together with military formations of other departments in the anti-terrorist operation and in the operation of the joint forces in the east of the state pointed out a number of shortcomings in the preparation of components of the security and defense sector. Training should ensure the acquisition of abilities both independently to carry out tasks as intended and jointly as part of joint forces and tactical groups.

The need to introduce new approaches to the training of security and defense forces requires improving the organization of joint (interdepartmental) training.

Based on the analysis of the organization of joint (interdepartmental) training, to determine the principal directions of increasing the efficiency of training of units of the security and defense sector of the state.

The article highlights the results of the analysis of the organization of joint (interdepartmental) training in the leading countries of the world and aims to disclose the necessary directions for the development of training for the security and defense sector. It will allow you to highlight the main directions, and in the future will allow you to form the necessary recommendations in order to improve the functioning of the combined (interdepartmental) training system.
\end{abstract}

Keywords: defence forces, joint training, analysis of experience, organization, leading countries of the world.

\section{References}

1. Doctrine of the use of state defense forces: 31 mach. 2020 p./General Staff of the Armed Forces of Ukraine. Kyiv: G. Staff., 2020. 35 c. (Normative document General Staff of the Armed Forces of Ukraine. Doctrine).
2. Doctrine of joint training of state defense forces: 21 jan. 2020 p./General Staff of the Armed Forces of Ukraine. Kyiv: G. Staff., 2020. 26 c. (Normative document General 
Staff of the Armed Forces of Ukraine. Doctrine).

3. Unified list (catalog) of capabilities of the Ministry of Defense of Ukraine, the Armed Forces of Ukraine and other components of the Defense Forces: 2020 p./ Ministry of Defence Ukraine. Kyiv: MoD, 2020. 626 c. (Normative document Ministry of Defence Ukraine. Catalog).

4. Sirotenko, A. Modern views on the forms and methods of application of groups of troops (forces) of the Armed Forces of Ukraine, other military formations, All-Ukrainian scientific-practical conference "Joint actions of military formations and law enforcement agencies of the state: problems and prospects", Odessa, 2018.

5. Zablocki, V. To ensure victory in the Great War, Ukrainian Week, Kyiv, 2019, Electronic resource. URL: https://tyzhden.ua/World/ 228985

6. Homa V. V. (2013) Requirements for general training and use of the Armed Forces and the
State Border Service of Ukraine: Collection of abstracts International conference. "Integrated border management: theory and practice", $132-133$

7. Yakymik S.V. (2018) Problematic issues of the use of forces (troops) of the Navy of the Armed Forces of Ukraine as part of interspecific and interdepartmental groups and ways to solve them: Collection of abstracts fifth All-Ukrainian scientificpractical conference. "Joint actions of military units and state law enforcement agencies: problems and prospects", 16-17.

8. Pechurov S. L. (2010) Military professionals in the Anglo-Saxon model of armed forces management: history and modernity. Moscow: LENAND, $176 \mathrm{c}$.

9. National Security Act: 26 jul. 1947 y./ Congress USA. Washington: Congress USA.,1947. 17 c. (US normative document. Law). 